\title{
BERHERMENEUTIK BERSAMA DERRIDA
}

\section{Frety Cassia Udang}

\author{
Institut Agama Kristen Negeri Manado \\ fretyudang@iakn-manado.ac.id \\ Diterima 28 Februari 2019 \\ Disetujui 5 April 2019
}

\begin{abstract}
Humans are interpretive beings; a creature that is always seeking meaning and understanding reality outside of himself. The process of understanding and understanding continues and is productive as long as humans are and exist in this life. As long as there is an effort to interpret and understand, hermeneutics play a role. This paper tries to see hermeneutic understanding as a means of criticizing the absoluteness and dominance of meaning and understanding from the perspective of Derrida Deconstruction. Hermeneutics in the perspective of deconstruction provides important space for readers and their context in constructing meaning. The various meanings and understandings are appreciated as a necessity of a process of reading texts. Through Derrida's glasses, deconstruction becomes a reflective tool to open new awareness and new possibilities, which may have been missed in the effort to understand

Keywords: Deconstruction, Derrida, Hermenutics, Understanding
\end{abstract}

\begin{abstract}
ABSTRAK
Manusia adalah makhluk penafsir; makhluk yang senantiasa mencari makna dan memahami realitas di luar dirinya. Proses memahami dan memaknai terus berlangsung dan produktif sepanjang manusia berada dan mengada dalam kehidupan ini. Selama ada upaya memaknai dan memahami, di situlah hermeneutik berperan.Tulisan ini mencoba melihat pemahaman hermeneutik sebagai sarana kritik terhadap keabsolutan dan dominasi makna dan pemahaman dari perspektif Dekonstruksi Derrida.Hermeneutik dalam perspektif dekonstruksi, memberi ruang penting bagi para pembaca dan konteksnya dalam membangun makna. Makna dan pemahaman yang beranekaragam diapresiasi sebagai keniscayaan dari sebuah proses pembacaan teks. Melalui kacamata Derrida, dekonstruksi menjadi sarana reflektif untuk membuka kesadaranbaru dan kemungkinan baru, yang mungkin selama ini terlewatkandalam upaya memahami
\end{abstract}

Kata Kunci : Dekonstruksi, Derrida, Hermenutik, Pemahaman

\section{LATAR BELAKANG}

Tulisan ini adalah buah perenungan disepanjang pengembaraan akademik kelas hermeneutik yang pernah saya ampu berkelindan dengan kenangan belajar tentang Jacques Derrida dalam kembara studi Teologi dan Hermeneutik di Program Pascasarjana Teologi UKDW. Pemaknaan tunggal, keterikatan pada dogmaatau kesimpulan-kesimpulan teologis yang sudah terlanjur dipegang teguh, dan keengganan untuk memaknai teks berbeda dari pemahaman biasanya adalah momok penghambat kreatifitas berpikir dalam rangka produktifitaspemahaman dan makna. Menurut Robert Setio, hermeneutik membahas konsep-konsep yang melahirkan 
pemahaman. ${ }^{1}$ Tugas hermeneutik tidak hanya mereproduksi dan merepetisi doktrin dan makna yang diwariskan turun temurun, tetapi memproduksi makna atas pembacaan teks sebagai yang otonom dan terus bertransformasi, bukan sebagai sesuatu yang telah dilabeli dan dibakukan. Hermeneutik adalah upaya memproduksi makna yang diperoleh dari pembacaan teks secara utuh dengan mempertimbangkan dan menggali segenap variabel teks tanpa ada yang terlewati, terabaikan atau sengaja ditutupi. Suatu upaya untuk membangun kesadaran bahwa kepelbagaian kemungkinan pembacaan atas teks dan keberagaman makna teks adalah keniscayaan. Melalui upaya hermeneutik, teks seharusnya dibebaskan dari penunggalan makna dan dirayakan sebagai realitas kemajemukan.

Memahami teks sebagai yang bermakna tunggal menjadi biang dari klaim pembenaran. Klaim pembenaran akan menjadi muara penolakan dan penghakiman terhadap yang lain. Konflik antar komunitas dan pribadi banyak terjadi karena ketidakmauan untuk menerima perbedaan. Persoalan demi persoalan tidak terselesaikan padahal tidak semиa soal harus diselesaikan dengan konsensus (kesepakatan). Persinggungan semakin

${ }^{1}$ Robert Setio, Deskripsi Hermeneutik dalam Bahan Bacaan Mata Kuliah Teologi dan Hermeneutik. (Yogyakarta : UKDW, 2008), h. 1 tajam karena yang berbeda dianggap sebagai oposisi. Keterpecahan tidak terelakkan karena kelaziman menjadi norma, yang tidak lazim dianggap pemberontakan.Kesenjangan terus terjadi karena ada makna yang monopolistis, di luar itu dianggap keliru. Paradigma berpikir seperti inilah yang harus diputuskan di tengah-tengah kenyataan kemajemukan yang tidak bisa diabaikan.

Tulisan ini tidak berbicara tentang realitas sistem dan konsep terlalu teologis atau agamis.Tulisan ini berbicara tentang hermeneutik sebagai aktifitas membaca dan memahami realitas. Aktifitas keseharian yang dilakukan manusia untuk menemukan makna atas teks.Ini adalah upaya literasi untuk menyampaikan kerinduan membangun kesadaran berpikir yang terbuka dan apresiatif terhadap perbedaan. Dengan memakai perspektif dekonstruksi Derrida, penulis mengajak para pembaca untuk menelusuri dan menggali setiap aspek teks. Seperti penuturan Mudji Sutrisno yang dikutip oleh Aloysius Baha Lajar :

“.....dekonstruksi (dari) Jacques Derrida yang mengajak kita membaca realitas sebagai teks baru dengan hak otonomi baca dan interpretasi baru dari tiap orang dan mulainya tidak dari 


tafsiran baku(kanon atau
center) tetapi mulai dari
pinggiran termasuk catatan
kaki, tanda-tanda baca, dan
aporia..."2

Tidak ada yang tidak bermakna dari sebuah teks. Bahkan dari setiap hal yang dianggap tidak bermakna (tidak penting) kita dapat menghasilkan makna.

Dalam pemahaman Derida, teks tidak hanya dalam bentuk tulisan atau nats.Teks adalah jejaring makna dan struktur symbol. Perilaku, tindakan, norma, mimic, tata nilai, isi pikiran, percakapan, benda-benda dan obyek sejarah dan lain sebagainya adalah teks. ${ }^{3}$ Segala sesuatu yang dapat dipahami, yang memiliki makna dan dapat diolah dengan akal itulah teks.Dalam konteks pengertian teks seperti inilah, teks dan makna dibicarakan dalam tulisan ini. Di tengah keluasan makna teks menurut Derrida dan keberagaman makna dalam perspektif dekonstruksi, maka berhermeneutik bersama Derrida adalah peziarahan menapaki jejak-jejak pemikiran Derrida di ruang keseharian kita yang tidak pernah lepas dari kegiatan membaca, memahami dan memaknai realitas.

\section{Derrida dan Dekonstruksi}

\footnotetext{
${ }^{2}$ Aloysius Baha Lajar, Jacques Derrida dan Perayaan Kemajemukan, dalam Mudji Sutrisno dan Hendar Putranto(ed.) :Teori-teori kebudayaan. (Yogyakarta : Kanisius, 2005), h. 163

${ }^{3}$ Pada umumnya teks hanya dipahami sebagai tulisan. Menurut KBBI, teks adalah naskah atau kutipan. Lihat F. Budi Hardiman, Seni
}

Derrida adalah seorang filsuf yang pemikirannya dianggap njelimettetapi anehnya menarik untuk dipelajari dan dikaji. Siapakah Derrida? Derrida bernama lengkap Jacques Derrida. ${ }^{4}$ Ia lahir pada tanggal 15 Juli dari sebuah keluarga Yahudi di El-Biar, Aljazair. Perjalanan studinya penuh dengan dinamika gagal sukses. Beberapa kali Derrida pernah gagal dalam ujian. Derrida berhasil diterima dan kuliah di Ecole Normal Superieure (ENS) Paris, setelah dua kali gagal dalam ujian masuk. Di ENS, Derrida menekuni bidang Psikologi dan Etnologi serta menjadi aktifis nonkomunis sayap kiri. Di ENS pun dia pernah gagal ujian lisan agregasi di bidang Psikologi, sampai pada akhirnya ia berhasil dan ditunjuk sebagai auditor khusus di beberapa universitas terkenal seperti Harvard, Cambridge dan Massachussetts.Derrida mengawali karir akademiknya dengan mengajar Filsafat dan Logika di The University of Paris. Derrida juga mengajar di almamaternya itu ENS Paris. Debutnya dalam kancah intelektual Amerika dimulai ketika ia mengikuti konferensi di Universitas John Hopkin Amerika pada tahun 1966 dan membawakan makalah yang berjudul : “

Memahami : Hermeneutika dari Schleiermarcher sampai Derrida, (Yogyakarta : Kanisius, 2015), h. 12

${ }^{4}$ Tentang riwayat hidup Derrida, disarikan dari tulisan A. Sudiarja, Jacques Derrida : Setahun sesudah kematiannya, dalam BASIS, No.11-12, November-Desember, 2005, h.5 
Structure, Sign and Play in the Discourse of the Human Sciense". Di situ ia mengemukakan penolakannya atas filsafat barat dengan gagasan yang kita kenal sebagai dekonstruksi.

Apakah dekonstruksi itu?Sebelum membahas dekonstruksi, maka penting untuk menelisik alasan mengapa Derrida mengajukan dekonstruksi?Dekonstruksi adalah bentuk penolakan terhadap perkembangan filsafat barat. ${ }^{5}$ Penolakan terhadap filsafat barat dilakukannya dengan mengkritik pandangan metafisika dan logosentrisme.Pandangan metafisika barat adalah metafisika kehadiran.Metafisika kehadiran menganggap seolah-olah kata, tanda dan konsep telah merepresentasikan atau menghadirkan being ${ }^{6}$.Pada zaman modern, logis mempengaruhi pola pikir manusia. Setiap filsuf berdebat tentang apa ini dan itu. Mereka menganggap ketika mampu memberi penjelasan tentang ini dan itu, maka penjelasan itu sudah mewakili realitas ini itu dan penjelasan tersebut dianggap benar.Metafisika kehadiran membekukan definisi dan identitas.Metafisika kehadiran inilah yang menjadi biang munculnya logosetrisme.Logosentrisme adalah tradisi

${ }^{5}$ Sudiarja, A \& Jacques Derrida, hlm. 4; H. Tedjoworo, Imaji dan Imajinasi, (Yogyakarta: Kanisius, 2009), h. 16; Aloysius Bahan Bajar, Teoriteori kebudayaan, h. 167; Turiman, Metode Semiotika Hukum Jacques Derrida, Jurnal Hukum dan Pembangunan, Tahun ke 44 No.7, April-Juni, 2015, h. 309 berpikir yangmenaruh kepercayaan penuh kepada rasio atau akal.Kecenderungan logosentrisme adalah keterpusatan terhadap kebenaran sendiri.Pandangan ini mengabaikan bahwa pada dasarnya setiap nalar memiliki konstruksi argumennya sendiri. Ciri yang menonjol dari logosentrisme adalah pola pikir biner; ada dua hal yang vis a vis atau saling beroposisi. Laki-laki $><$ perempuan, $\quad$ siang $><$ malam, rohani $><$ jasmani,lisan $><$ tulisan dst. Apakah yang menjadi persoalan dari pola pikir biner?Pola pikir biner sesungguhnya bukanlah sebuah persoalan apabila dua hal yang beroposisi ada dalam keadaan setara. Persoalan muncul ketika satu term menguasai term yang lain. Ketika satu term dalam oposisi itu diunggulkan dari term yang lain, bahkan menjadi sumber makna bagi term yang lain. Misalnya, kata perempuan memperoleh makna hanya bila dikaitkan dengan laki-laki, sedangkan kata laki-laki seolah-olah punya maknanya sendiri.Inilah yang disebut Derrida, hierarki yang brutal. ${ }^{7}$ Dalam konteks paradigma oposisi biner, dekonstruksi hadir tidak untuk membalikkan tatanan oposisi, yang didominasi menjadi yang mendominasi ataupun mendamaikan keduanya.

${ }^{6}$ Turiman, Metode Semiotika Hukum Jacques Derrida, Jurnal Hukum dan Pembangunan, Tahun ke 44 No.7, April-Juni, 2015, h. 310.

${ }^{7}$ Sumarwan, A., Membongkar yang lama, menenun yang baru, dalam BASIS, No.11-12, November-Desember, 2005, h. 19 
Dekonstruksi tidak mensistesiskan antara tesis dan antithesis, melainkan mencari alternatif lain, yang melampaui oposisi biner.Dekonstruksi mewadahi sikap dan pola pikir yang menjunjung keterbukaan dan kesetaraan, tanpa harus ada keseragaman, melainkan membiarkan dinamika perbedaan itu tetap terjaga harmonis dan dihormati.

Penghargaan terhadap keragaman ini, didukung juga oleh pemikiran Derrida mengenai différance (Prancis). Différance adalah sumber makna yang ekuivok. Mengapa makna ekuivok (plural)? Karena tiap teks memiliki différance; memiliki jejak-jejak perbedaan. Misalnya sebuah kata itu hanya merujuk kepada tanda yang lain dan tidak pernah berakhir pada obyek tertentu sebagai penjelas final. Jejak pada kata merujuk pada apa yang ada sekaligus apa yang tidak ada. Misalnya ketika seorang anak melihat anjing. Dia bertanya : “Apa itu?" orang menjawab : "itu anjing". Lagi si anak bertanya : "Anjing itu apa?". Kembali di jawab : 'Anjing itu binatang!". Sahut si anak : "Binatang itu apa?". Dijawab lagi, "Binatang itu makhluk hidup!”. Kembali anak menyelutuk : “ Makhluk itu apa? Hidup itu apa?" dan seterusnya. Jadi apapun ide dan gagasan yang kita miliki, itu hanyalah satu lini jejak dari teks, maka jangan buru-buru
menyimpulkan.Tidak boleh ada klaim kebenaran atas satu makna.Apa itu dekonstruksi?

Dekonstruksi merepresentasikan hasrat dan cita-cita untuk membongkar bangunan yang sudah mapan; suatu upaya mempreteli sebuah konstruksi yang baku; suatu 'gerakan' anti-kemapanan.Banyak yang menganggap dekonstruksi bukan sebagai upaya intelektual yang serius, tetapi hanya sekedar permainan pikiran yang nihilistik. Tetapi, apabila kita berbicara tentang hermeneutik, menurut Heidegger dalam pengertian Yunani Kuno, hermeneutik dipahami sebagai "pikiran yang bermain", ketimbang "ilmu yang ketat.Keseriusan orang modernlah yang membuat hermeneutik menjadi pengetahuan metodologis yang rumit ${ }^{8}$. Jadi, mengapa pengertian hermeneutik dalam kerangka permainan pikiran ini dianggap keliru dan tidak berguna?

\section{Hermeneutik: Membaca teks dari tepian!}

Ketika berbicara tentang hermeneutik, kita sedang berbicara mengenai makna dari suatu teks atau realitas. Makna selalu ditemukan melalui penafsiran. Ketika manusia berhadapan dengan teks(realitas) ia akan membuat penafsiran untuk memahami teks(realitas). Sebagai makhluk penafsir, semua yang 
"tertangkap" oleh manusia tidak lepas dari penafsiran. Namun bagaimana manusia dapat mencapai pemahaman akan makna, sedangkan ada jarak antara manusia dan teks? Di sinilah percakapan hermeneutik itu muncul. Hermeneutik mencoba menjembatani jarak antara dunia kita (kini) dengan sesuatu yang lain, yang hendak kita pahami dan masukkan dalam horison pemahaman kita. Maka inilah poin dari apa yang sudah diungkapkan di bagian pendahuluan, bahwa hermeneutik selalu terkait dengan pemahaman. Pertanyaan selanjutnya : "bagaimana memahami itu?'Perlu digarisbawahi bahwa tulisan ini tidak membahas konsep-konsep hermeneutik secara luas.Hermeneutik yang dibicarakan dalam tulisan ini ada dalam kerangka pemahaman terbatas dalam kaitannya dengan teori dekonstruksi.

Sejak masa pencerahan muncul pemahaman bahwa memahami dan memaknai selalu bertolak dari makna

\footnotetext{
${ }^{9}$ Aloysius Baha Lajar, hlm. 171. Pemahaman tentang teks yang memiliki makna transenden dan universal, juga pernah dikemukakan diantarannya oleh E.D. Hirsch. E.D.Hirsch berpendapat bahwa teks merupakan entitas yang selalu tinggal atau ada secara sama dari satu waktu ke waktu seterusnya. Teks memiliki makna obyektif dan kekal yang tidak terikat pada satu konteks saja. Dengan kata lain Hirsch menyatakan bahwa ada makna yang bersifat universal. Pendapat Hirsch inilah yang kemudian ditanggapi oleh Stanley Fish yang berpendapat bahwa teks menjadi bermakna tidak lepas dari perspektif asumsi penafsir. Pemahaman terhadap maknatidak terletak di luar sebagai suatu realitas obyektif, tetapi terikat pad asumsi yang dibentuk oleh konteks, sistem ataupun juga penafsiran komunitasnya (Baca Stanley Fish, Is
}

obyektif asali suatu teks. Suatu teks diandaikan memiliki kualitas obyektif yang memiliki determinasi makna dari dirinya sendiri. Setiap membaca teks, kita dipaksakan masuk dalam horison makna yang tunggal dan mutlak itu. Oleh karena itu yang bisa kita lakukan adalah menerima atau menolaknya. Bagi Derrida tidak ada teks yang dibatasi oleh dasar transenden. ${ }^{9}$ Sebuah teks senantiasa berkorelasi dengan konteks, sehingga selalu ada peluang munculnya makna lain yang berkelindan dengan konteks.Kenyataan teks adalah equivok bukan univok. ${ }^{10}$ Setiap orang boleh membaca teks(realitas) yang sama tetapi setiap orang berpeluang untuk menciptakan makna dan memahami teks berbeda-beda. Perayaan kemajemukan inilah yang menjadi salah satu dasar perjuangan dekonstruksi Derrida.

Berhermeneutik bersama Derrida, seolah secara gamblang meletakkan posisi

there a text in this class?, Harvard University Press, 1980, bab 3\&13).

${ }^{10}$ Istilah ekuivok adalah istilah dalam ilmu logika.Ekuivok merujuk pada kata yang mempunyai makna lebih dari satu dan pada umumnya memiliki dua makna. Kata Ekuivok menyatukan dua gagasan atau hal yang sama sekali berbeda di bawah kata yang sama. Istilah ekuivok relevan digunakan dalam membahas teori dekonstruksi Derrida, karena dalam dekonstruksi sebuah teks/realitas yang sama dapat dimaknai dan memunculkan gagasan yang berbeda, lihat

https://cafestudi061.wordpress.com/2008/12/02/am bigu-univok-equivok-dan-analog/; lihat juga paparan Dr. Fahruddin Faiz, Jacques Derrida, dalam https://www.media-koentji.site/2019/06/downloadfile-ngaji-filsafat.html; 
dekonstruksi sebagai sebuah metode, padahal menurut Derrida, dekonstruksi itu pas de method.Derrida dan para pengikutnya pada umumnya menolak mendefinisikan dekonstruksi, sebab menurut mereka, definisi adalah pembatasan sedangkan dekonstruksi adalah upaya menerobos batas. Apakah itu berarti menggunakan istilah hermeneutik dalam kerangka berpikir dekonstruksi itu tidak relevan? A. Sumarwan menurut Simon Critchley dalam The Ethics of Deconstruction: Derrida and Levina(1992:22) mengatakan bahwa pemikiran Derrida selalu merupakan pemikiran tentang sebuah teks dan dekonstruksi selalu terkait dengan pembacaan atas sebuah teks, ${ }^{11}$ disementara itu hermeneutik juga selalu berurusan dengan teks dan pembacaan terhadap teks. Dekonstruksi berbicara tentang produksi makna, demikian juga hermeneutik tidak pernah lepas dari usaha penemuan makna.Jadi dapatlah dikatakan bahwa dekonstruksi adalah salah satu strategi interpretasi teks (realitas). Seperti kerangka berpikir dekonstruksi yang menawarkan cara memahami teks secara terbuka dan terus menerus bertransformasi, maka tidaklah berlebihan apabila acuan Derrida dan pengikutnya bahwa dekonstruksi bukan

\footnotetext{
${ }^{11}$ Sumarwan, A., Membongkar yang lama menenun yang baru, h.17
}

metode, dalam dinamika pembacaan dan pemahaman yang baru, malah dipahami sebagai metode atau prosedur penafsiran teks. Jadi anggaplah dekonstruksi diletakkan sebagai strategi analisa teks.

Dekonstruksi dikategorikan dalam kelompok hermeneutik radikal.Sifat radikalis ini ditandai dengan pergantian perpektif terus-menerus sehingga makna “tidak dapat diputuskan”.Teks dapat diinterpretasikan sampai tidak terhingga. Apabila makna sudah ditemukan, makna itu terbuka terhadap kemungkinan ditemukan makna yang lain dan demikian seterusnya. Penemuan makna yang baru, tidak membatalkan makna yang dahulu, tetapi makna yang dahulu tidak boleh menjadi acuan atau pusat. Seperti kata F. Budi Hardiman dalam sebuah kuliah kelas Filsafat bahwa seorang pembaca dekonstruksi tidak akan memberikan jawaban apa makna teks itu, tetapi hanya akan bisa mengatakan, "ada makna ini, ada makna itu...tetapi makna yang sesungguhnya, saya tidak bisa memutuskan." Maka akan berbeda dengan para pembaca positifis yang akan mengatakan dengan tegas "maknanya ini!" "Sifat radikalis itu juga tampak pada konsistensi dekonstruksi untuk memperhatikan "tepian" teks.Tepian

\footnotetext{
${ }^{12}$ Memahami Teori Dokunstruksi Jacques Derrida sebagai Hermeneutika Radikal _ Lingkar Studi Filsafat Discourse.mhtml;
} 
merepresentasikan variabel-variabel yang terlewati dan terabaikan karena dominasi satu makna dan pengagungan status quo. Diandaikan pusat merepresentasikan kebenaran yang mendaku dan mutlak, maka dekonstruksi memastikan bahwa tepi-tepi teks pun memuat beragam makna yang layak untuk diperhitungkan dan diapresiasi. Berhermeneutik bersama Derrida berarti menjejaki tiap tepian teks sebagai oase makna, menggeser kemapanan makna yang terpusat, utama, tunggal dan mutlak, secara ad absurdum mendeskripsikan dan mentransformasi makna sesuai konteks, dan menghargai kepelbagaian sudut pandang yang menjadi muara penghormatan terhadap perbedaan serta sadar bahwa sesuatu yang dianggap "benar" harus terus mengalami dekonstruksi.

Hermeneutik: menggugat hirarkisme, menyanjung kesetaraan

Hermeneutik dalam bingkai dekonstruksi adalah membaca dan memahami teks dengan paradigma kesetaraan dan keragaman.Tidak ada hierarkisme dan dominasi. Yang ada adalah kesadaran tentang keluasan makna, kedalaman arti, keberagaman pemahaman dan proses transformasi makna yang harus terus berlangsung. Kita harus mengakui

\footnotetext{
${ }^{13}$ Haryatmoko, Kutukuan Logika Ekonomi: Tak mungkin memberi tanpa mengharap
}

bahwa ada begitu banyak paham dan kesimpulan yang sangat hierarkis baik dalam dogma dan kesimpulan teologis yang kita pegang, dalam pola relasi sosial yang kita bangun, dalam bahasa dan perilaku keseharian serta identitas yang dilekatkan.Di atas telah disinggung mengenai salah satu presentasi logosentrisme adalah pola pikir biner atau oposisi biner.Konsekuensi binery opposition adalah hierarkisme brutal kata Derrida.Hierarkisme inilah yang menjadi sumber konflik.Dalam perspektif dekonstruksi, klaim keutamaan, klaim kebenaran, dan penyeragaman adalah awal kekerasan dan kemunafikan. ${ }^{13}$ Oleh karena itu hermeneutik dalam bingkai dekonstruksi adalah membaca dan memahami teks atau realita dalam rangka mematahkan hierarki dan menyeimbangkan apa yang timpang. Memberi kesempatan kepada dua entitas berhadapan secara setara dan damai.Bilamana itu terjadi?Mungkinkah itu terjadi di tengah dunia yang konstruksinya senjang?

Dekonstruksi membuka kemungkinan terbukanya jalan bagi harmonisasi dua entitas yang berbeda. Harmonisasi bukan kompromi untuk seragam atau sama, tetapi membiarkan

kembali, dalam BASIS,No.11-12, NovemberDesember, 2005, h. 8 
nuansa dari tiap entitas tetap ada, tanpa ada yang disuperioritaskan dan disubordinasikan. Dekonstruksi juga pada dasarnya berbicara tentang pembalikan tatanan.Misalnya, ketika kita berbicara tentang laki-laki dan perempuan tidak hanya berbicara tentang jenis kelamin manusia tetapi juga konstruksi sosial lakilaki dan perempuan.Tetapi juga tidak hanya tentang konstruksi sosial, namun sampai pada gerakan-gerakan perlawanan dan emansipatif terhadap konstruksi timpang antara laki-laki dan perempuan.Dalam rangka melawan superioritas maskulin dan dominasi patriarkhi (kutub laki-laki) maka ada gerakan perlawanan dari kutub perempuan yang disebut gerakan feminis.Banyak definisi dan pengertian tentang feminis, tetapi pada dasarnya perlawanan feminis berorientasi pada perjuangan untuk kesetaraan antara lakilaki dan perempuan. Kesetaraan bukan berarti sama, karena pada hakekatnya lakilaki dan perempuan memang berbeda secara fisik, psikis, dan perspektif. Dalam perspektif dekonstruksi, feminis harus secara terang menunjukkan bahwa ada kekerasan oposisi biner lakilaki $><$ perempuan dan berjuang mengatasi ketidaksetaraan itu.Pembalikkan tatanan ini harus dilakukan dengan mendekonstruksi atau membongkar secara total. Namun, pembalikkan dan pembongkaran, tidak dalam rangka membalikkan 'yang mendominasi' menjadi 'yang didominasi' dan sebaliknya 'yang didominasi' menjadi 'yang mendominasi'. Dekonstruksi berupaya mencari tatanan alternatif.Seperti yang telah diungkapkan sebelumnya, mencari tatanan alternatif yang melampaui oposisi biner.Tatanan alternatif ini mengambil posisi ambang. Ketika pola pikir oposisi biner hanya terbatas pada pilihan kalau bukan A berarti non-A, kalau bukan non-A berarti A, dekonstruksi membuka kemungkinan bukan hanya $\mathrm{A}$ atau non-A, tetapi mungkin B,C,D dan seterusnya atau non-B, non-C, non-D dan seterusnya. Yang paling utama tatanan ini mengarusutamakan kesetaraan dalam setiap lini pemahaman dan pemaknaan terhadap teks atau realitas, sehingga tidak ada hierarkisme.

Hermeneutik dalam perspektif dekonstruksi, berupaya membaca dan memahami teks atau realita secara seimbang dan setara untuk menghasilkan pemahaman dan pemaknaan yang seimbang dan setara juga, tetapi sekaligus apa yang seimbang dan setara ini akan terus menerus didekonstruksi sehingga pemahaman dan maknanya terus menerus bertransformasi untuk menjawab konteks. Seperti pendapat Trisno Sutanto, Derrida melalui tawaran dekonstruksinya:

$$
\begin{aligned}
& \text { “.. membuka seluruh } \\
& \text { kompleksitas dan mendorong } \\
& \text { kita memasuki dan bermain di } \\
& \text { dalam medan pemaknaan yang }
\end{aligned}
$$


terus bergerak, di dalam ketegangan yang tidak pernah final..."14

Berhermeneutik bersama Derrida, membuka pandangan kita untuk terus melakukan perjalanan menemukan makna dan tidak membiarkan teks dan makna terjebak di horizon hitam-putih yang hierarkis, melainkan membawa teks dan makna memasuki horizon bebas dominasi untuk melahirkan makna baru secara terus menerus. Setiap pembaca teks masuk dalam horizon keberagaman makna, toleran terhadap keberagaman itu dan merayakannya dengan cara menghargai segala kemungkinan makna yang ada.

\section{Akhirnya ...}

There is nothing outside the text kata Derrida. Tidak ada sesuatupun di luar teks.Makna ada di dalam teks.Teks merupakan entitas yang independen, memuat jaringan makna yang sangat luas, dan makna yang kita simpulkan hanyalah satu dari jaringan makna.Makna yang kita simpulkan pun tidak boleh lepas dari konteks dimana kita melakukan pembacaan.

Dekonstruksi sebagai salah satu ciri kritik postmodernisme, tidak harus

14 Trisno Sutanto, Adieu : Berteologi bersama Derrida, Bahan Diskusi di Teater Utan Kayu, Jakarta, 2005, h. 3 dipahami secara negative sebagai upaya pembongkaran. Dekonstruksi merupakan tanggapan terhadap usaha manusia modern memahami dirinya di tengah-tengah dunia ini. ${ }^{15}$ Ketika dunia modern berupaya membuat metanarasi yang obyektif dan unggul serta dianggap dapat dipaksakan untuk relevan bagi seluruh konteks yang berbeda, maka dekonstruksi hadir untuk menyadarkan adanya identitas differensiasi sebagai hakekat dalam dunia ini untuk menjadi titik berangkat penting bagi setiap orang untuk memahami teks atau realitas. Inilah hasil pembacaan penulis atas Derrida, mungkin ada hasil pembacaan yang berbeda tentang Derrida dari penulis atau orang lain, tetapi sama seperti Derrida yang berupaya merayakan keberagaman dalam pemikirannya, maka biarlah perbedaan itupun menjadi warna dalam upaya kita membaca Derrida dan pemikirannya. Pada akhirnya selamat berhermeneutik: membaca dan memahami realitas dalam keunikan dan kekhususan konteksmu!!

\section{DAFTAR PUSTAKA}

Singgih, Gerrit, Emanuel, Menguak Isolasi, Menjalin Relasi : Teologi Kristen dan tantangan dunia postmodernisme. Jakarta: BPK GunungMulia, 2009.

${ }^{15}$ Emanuel Gerrit Singgih, Menguak Isolasi, Menjalin Relasi : Teologi Kristen dan tantangan dunia postmodernisme,(Jakarta: BPK Gunung Mulia, 2009), h. 145 
Hardiman, Budi, F. Seni Memahami :Hermeneutika dari Schleiermarcher sampai Derrida. Yogyakarta: Kanisius, 2015

Tedjoworo, $\mathrm{H}$, Imaji dan Imajinasi. Yogyakarta: Kanisius, 2009

Robert,

Setio,DeskripsiHermeneutikdalam BahanBacaan Mata KuliahTeologi dan Hermeneutik,.Yogyakarta : UKDW, 2008.

Stanley Fish,Is there a text in this class. Harvard University Press, 1980

\section{Jurnal dan Artikel}

BASISMenembus Batas, EdisiKhusus Derrida, No.11-12, NovemberDesember, 2005,

JurnalHukum dan Pembangunan, Tahunke 44 No.7, April-Juni, 2015

Trisno, Sutanto, Adieu: Berteologibersama Derrida, BahanDiskusi di TeaterUtanKayu, Jakarta, 2005

Turiman, Metode Semiotika Hukum Jacques Derrida, Jurnal Hukum dan Pembangunan, Tahun ke 44 No.7, April-Juni, 2015

Ambigu, Imam, K, univok, equivok dan analog dalam https://cafestudi061.wordpress.com /2008/12/02/ambigu-univokequivok-dan-analog/

FahruddinFaiz, Jacques Derrida, dalamhttps://www.mediakoentji.site/2019/06/download-filengaji-filsafat.html 